\title{
Development of Time-Resolved Fluorescence Immunochromatographic Assays for Simultaneously Detecting Tylosin and Tilmicosin in Milk in Group-Screening Manner
}

\author{
Yu Wang ${ }^{1,2,+}$, Jin-Yi Yang ${ }^{1,+} \oplus$, Ying $\mathrm{He}^{1}, \mathrm{Lu} \mathrm{Li}^{1}{ }^{1}$, Jian-Xin Huang ${ }^{1}$, Yuan-Xin Tian ${ }^{3} \oplus$, Hong Wang ${ }^{1}$, \\ Zhen-Lin $\mathrm{Xu}^{1}$ (D) and Yu-Dong Shen ${ }^{1, *(D)}$ \\ 1 Guangdong Provincial Key Laboratory of Food Quality and Safety, College of Food Science, \\ South China Agricultural University, Guangzhou 510642, China; xxwangyu@163.com (Y.W.); \\ yjy361@163.com (J.-Y.Y.); heyin4102021@163.com (Y.H.); lilu5082021@163.com (L.L.); \\ bi@stu.scau.edu.cn (J.-X.H.); gzwhongd@163.com (H.W.); jallent@163.com (Z.-L.X.) \\ 2 Guangzhou Institute for Food Inspection, Guangzhou 510410, China \\ 3 Guangdong Provincial Key Laboratory of New Drug Screening, School of Pharmaceutical Sciences, \\ Southern Medical University, Guangzhou 510515, China; tyx523@163.com \\ * Correspondence: shenyudong@scau.edu.cn; Tel.: +86-20-8528-3448 \\ + Both authors contributed equally to this work.
}

check for updates

Citation: Wang, Y.; Yang, J.-Y.; He, Y.; Li, L.; Huang, J.-X.; Tian, Y.-X.; Wang, H.; Xu, Z.-L.; Shen, Y.-D. Development of Time-Resolved Fluorescence Immunochromatographic Assays for Simultaneously Detecting Tylosin and Tilmicosin in Milk in Group-Screening Manner. Foods 2021, 10, 1838. https:/ / doi.org/10.3390/foods10081838

Academic Editor: Manuel

Castillo Zambudio

Received: 15 July 2021

Accepted: 5 August 2021

Published: 9 August 2021

Publisher's Note: MDPI stays neutral with regard to jurisdictional claims in published maps and institutional affiliations.

Copyright: (c) 2021 by the authors. Licensee MDPI, Basel, Switzerland. This article is an open access article distributed under the terms and conditions of the Creative Commons Attribution (CC BY) license (https:// creativecommons.org/licenses/by/ $4.0 /)$
Abstract: Tylosin and tilmicosin (T\&T) residues in livestock products have received extensive attention from consumers. Time-resolved fluorescence immunochromatographic assay (TRFICA), as a fast, efficient and sensitive immunoassay method, has played an increasingly important role in the food safety field. Therefore, herein a quantitative and visual TRFICA was established for simultaneously detecting T\&T in milk in a group-screening manner. Under the optimal conditions, the standard curve range of developed TRFICA based on the T\&T was $1.87 \sim 7.47 \mathrm{ng} / \mathrm{mL}$, and the half-maximal inhibition concentrations $\left(\mathrm{IC}_{50}\right)$ were $4.06 \mathrm{ng} / \mathrm{mL}$ and $3.74 \mathrm{ng} / \mathrm{mL}$, respectively. The limits of detection (LOD) of the TRFICA method were from $1.72 \mathrm{ng} / \mathrm{mL}$ to $1.39 \mathrm{ng} / \mathrm{mL}$, and the visual cut-off values were $31.25 \mathrm{ng} / \mathrm{mL}$ and $62.50 \mathrm{ng} / \mathrm{mL}$ for T\&T in milk, respectively. Moreover, the stability experiments showed that the strips could be stored at $4{ }^{\circ} \mathrm{C}$ for more than 6 months, the total detection time was less than $13 \mathrm{~min}$, and the cross-reactivities (CRs) with related compounds were less than $0.1 \%$, which concluded that the developed TRFICA method could be used in real milk sample detection.

Keywords: time-resolved fluorescence immunochromatographic assay; tylosin; tilmicosin; milk

\section{Introduction}

$\mathrm{T} \& \mathrm{~T}$ are the most common premix macrolide antibiotics (Figure 1), which belong to an important class of antibiotics that inhibit Gram-positive and Gram-negative bacteria [1]. They are widely applied to animal production to prevent respiratory and enteric infections in cattle $[2,3]$. In addition, $T \& T$ are used as feed additives to promote animal growth and increase feed utilization [4,5], which could be accumulated as residues in the animal's body fluids and tissues [6]. However, both of them have been banned from animal feed in the European Union since 1999 [2]. The maximum residue limits (MRLs) range from 0.05 to $1.5 \mathrm{mg} / \mathrm{kg}$ for food samples [7]. Hence, detection of residues in contaminated milk remains a major issue because of its potential risk to human health, such as allergies and drug resistance [8-11].

Multiple technologies have been applied to detect residues of T\&T in food, such as high-performance liquid chromatography (HPLC), micellar electrokinetic capillary chromatography (MECC), high-performance liquid chromatography-tandem mass spectrometry (HPLC-MS/MS), and liquid chromatography-tandem mass high-resolution spectrometry (LC-HRMS) [12-17]. However, sophisticated and expensive equipment, professional 
personnel, and complex preprocessing methods are needed for the above methods $[17,18]$, and existing research methods are somewhat limited in that they cannot detect multiclass residues [19]; importantly, they are not convenient for on-site diagnostics. A microbiological assay is time-consuming and has poor specificity for the target due to the interference of detection duration and the presence of active antibacterial substances (enzymes, antibodies, etc.) in milk [20,21]. Immunoassays are characterized by specificity, high throughput, and sensitivity, as well as low cost and easy operation. Enzyme-linked immunosorbent assay (ELISA) has been widely used for rapid detection of T\&T in food samples [22-24]. Lateral flow immunoassay (LFIA) was developed to analyze six macrolide antibiotics in breast milk using latex particles labeled with BSA-clarithromycin antibody [25]. ELISA is used frequently for its high sensitivity, portability, and high throughput screening, but it was easily affected by matrix effects [26,27]. Meanwhile, previous studies have developed the ELISA method for detecting T\&T simultaneously, which is cheap, has high sensitivity, large capacity, and easy operation [1,28]. Immunochromatographic assay (ICA) is a more portable and faster assay than ELISA. As labeled nanomaterials of the ICA, quantum dot embedded luminescent beads have been used to detect TYL residues in honey and milk specifically [29]. Lanthanide chelates have unique fluorescent properties, such as high quantum yields, narrow band emission peak, long stoke shift, and fluorescence lifetime. Time-resolved fluoroimmunoassay (TRFIA) has higher sensitivity than most of the conventional methods, while they decrease the matrix interference in the assay [26,30]. An $\mathrm{Eu}^{3+}$ fluorescent lanthanide-based TRFIA for detecting T\&T in edible tissues is described, which offers cost and efficiency advantages, as well as simplified analysis steps [31]. Li et al. developed an LFIA based on the antibody-labeled time-resolved fluorescent microspheres (TRFM) as tracers; the cutoff values for T\&T in milk were $2 \mathrm{ng} / \mathrm{mL}$ and $4 \mathrm{ng} / \mathrm{mL}$, respectively [32].

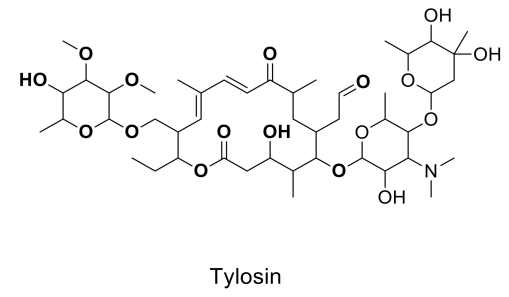

(a)

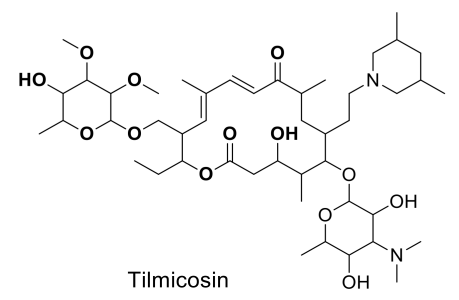

(b)

Figure 1. The structures of the molecules: (a) tylosin; (b) tilmicosin.

In this study, a TRFICA with high sensitivity and low cost for T\&T detection based on high-quality monoclonal antibody was developed successfully, the detailed conditions of Mab, coating antigen, and Immunoglobulin G (IgG) were optimized, and the standard curve of T\&T was developed. The TRFICA has high stability, specificity on T\&T, and neglect cross-reactivity on drugs with similar structures. The TRFICA could be used in milk detection without complicated sample preparation.

\section{Materials and Methods}

\subsection{Materials and Instruments}

Tylosin, tilmicosin, benfloxacin, enrofloxacin, azithromycin, acetylspiramycin, roxithromycin, clinfloxacin, pefloxacin, furazolidone, spiramycin, furandanone hydrochloride, and furantoin were purchased from Aladdin Reagent (Shanghai, China) Co., Ltd. Abamectin, erythromycin, florfenicol, and chloramphenicol were purchased from Energy Chemical Reagent (Shanghai, China) Co., Ltd. Florfenicolamide was purchased from Shanghai Macklin Biochemical Co. Ltd. Dimethylsulfoxide, 1-(3-Dimethylaminopropyl)-3ethylcarbodiimide hydrochloride) (EDC), N-Hydroxysuccinimide (NHS), dicyclohexylcarbodiimide (DCC), bovine serum albumin (BSA), ovalbumin (OVA), Freund's adjuvant (complete and incomplete), goat anti-mouse Immunoglobulin G (IgG), Casein, Trehalose, 2-(Nmorpholine) ethanesulfonic acid monohydrate (MES), Tris, Proclin-300, Polyvinylpyrrolidone (PVP) and Tween-20 were purchased from Sigma-Aldrich (St. Louis, MO, USA). 
Monoclonal antibody was obtained from South China Agricultural University (Design of Novel Haptens and Development of Monoclonal Antibody-based Immunoassays for the Simultaneous Detection of Tylosin and Tilmicosin in Milk and Water Samples, Biomolecules, 2019, 9(12): 770). Time-resolved fluorescent microsphere (catlog: FT02C, diameter: $100 \mathrm{~nm}$, laser: $360 \mathrm{~nm}$, emission: $610 \mathrm{~nm}$, surface function: $\mathrm{COOH}$ ) was purchased from Suzhou Vdo Biotech Co., Ltd. (Suzhou, China). Nitrocellulose membrane, sample pad (8694), and adsorbent pad (H-8) were from Shanghai Jieyi Biotechnology Co.,Ltd (Shanghai, China). The ELISA kit for tylosin analysis was obtained from Beijing Kwinbon Biotechnology Co., Ltd. (Beijing, China). Female BALB/c mice were purchased from Guangdong Medical Laboratory Animal Center (Guangzhou, China). Buffers were prepared in our laboratory. Solution A: $0.025 \mathrm{M}, \mathrm{pH}$ 6.5, 2-morpholinoethanesulfonic acid buffer. Solution B: $0.5 \mathrm{~g} / \mathrm{L}$ Casein, $0.05 \%$ Proclin-300, and $2 \mathrm{~g} / \mathrm{L}$ BSA in $0.05 \mathrm{M}$, pH 8.0 Tris- $\mathrm{HCl}$ buffer. Solution C: $0.05 \mathrm{M}$, pH 6.5 borate buffer. Solution S: $20 \mathrm{~g} / \mathrm{L}$ Trehalose, $0.2 \%$ Tween-20, 0.5\% Proclin-300, $2 \mathrm{~g} / \mathrm{L}$ BSA in $0.05 \mathrm{M}$, pH8.0 Tris- $\mathrm{HCl}$ buffer. Sample pad pretreatment solution: $0.05 \%$ Tween-20, 0.025 M PBS (pH 7.4), 0.5 g/L PVP, $15 \mathrm{~g} / \mathrm{L}$ sucrose, 0.02\% S9 surfactant. All other chemicals were purchased from Guangzhou chemical reagent Co., Ltd. (Guangzhou, China) and were of analytical grade or better, which the percentage concentrations were defined by weight unless otherwise specified. HM3030/HM3035 Dot Dispenser and Programmable strip cutter ZQ3500 were purchased from Shanghai Kinbio Tech.Co., Ltd. (Shanghai, China). U3010 Trace Ultraviolet Visible Spectrophotometry, Multiskan MK3 Microplate Reader, Nano Drop 2000C ultra-violet spectrophotometer were purchased fromThermo Scientific (Waltham, MA, USA). DEM-3 automatic plate washer (Top Analytical Instruments Co., Ltd., Beijing, China), time-resolved immunochromatography reader (Nanjing Microdetection Bio-Tech Co., Ltd.) and AB SCIEX 5500 triple quadrupole mass spectrometer (AB SCIEX, Redwood City, CA, USA) were used.

\subsection{Activation and Coupling of TRFM}

A total of $100 \mu \mathrm{L}$ TRFM that was modified with carboxyl groups was centrifuged at $1.37 \times 10^{6} \mathrm{~g}$ for $20 \mathrm{~min}$. The fluorescent microspheres were evenly dispersed in $400 \mu \mathrm{L}$ of solution A by ultrasonic stirring for $4 \mathrm{~min}$ after the supernatant was removed. A total of $50 \mathrm{mg} / \mathrm{mL}$ EDC and NHS mixed solution was prepared with solution A, $10 \mu \mathrm{L}$ of which was added to activate the carboxyl group on the fluorescent microsphere particles for the convenience of antibody coupling. The above solution was fully mixed with ultrasonic stirring for $4 \mathrm{~min}$ and shaken for $30 \mathrm{~min}$. The mixed solution was centrifuged at $1.37 \times 10^{6} \mathrm{~g}$ for $20 \mathrm{~min}$; then, the supernatant was removed. The above precipitation was remixed with $400 \mu \mathrm{L}$ of solution $\mathrm{C}$ by ultrasonic stirring for $4 \mathrm{~min}$, and the supernatant was removed by centrifugation $\left(1.37 \times 10^{6} \mathrm{~g}, 8{ }^{\circ} \mathrm{C}, 15 \mathrm{~min}\right)$. A total of $400 \mu \mathrm{L}$ of solution $\mathrm{C}$ was added to the above precipitation by ultrasonic stirring for $4 \mathrm{~min}$. An equal volume of monoclonal antibody was added to the redissolved solution and vortexed for $2.5 \mathrm{~h}$. The supernatant of solution was removed by centrifugation $\left(1.37 \times 10^{6} \mathrm{~g}, 8{ }^{\circ} \mathrm{C}, 15 \mathrm{~min}\right)$, and $400 \mu \mathrm{L}$ of solution $B$ was added to seal the non-specific binding sites on the surface of the fluorescent microspheres, sonicated for $4 \mathrm{~min}$ and shaken for $1 \mathrm{~h}$, then removed the supernatant by centrifugation $\left(1.37 \times 10^{6} \mathrm{~g}, 8^{\circ} \mathrm{C}, 15 \mathrm{~min}\right)$. Finally, $400 \mu \mathrm{L}$ of solution $\mathrm{S}$ was added with ultrasonic stirring for $4 \mathrm{~min}$, then was stored in the dark at $4{ }^{\circ} \mathrm{C}$ for further use.

\subsection{Optimizing the Amount of Monoclonal Antibody Conjugated to Fluorescent Microspheres}

Europium-chelated fluorescent microspheres with carboxyl activated group were used to conjugate the monoclonal antibody. Based on the existing research results [33,34], the amount of activated microspheres $(10 \%, 100 \mathrm{~nm})$ was fixed at $25 \mu \mathrm{L}$, and the amount of conjugated monoclonal antibody was optimized at 5-100 $\mu$ g according to the quality of different antibodies. The different standard curves were established based on the fluorescent microspheres with different monoclonal antibodies. The antibody dosage was optimized and screened by comparing the color of the test strip and the $\mathrm{IC}_{50}$ of developed standard curve. 


\subsection{Selection of Microsphere-Labeled Antibody}

An appropriate volume of fluorescent microsphere-labeled antibody was added in microwell plate to react with the target analyte. Excessive labeled antibodies would make the absorbance value too large and reduce its sensitivity. The detection standard curves were established based on different volumes of labeled antibodies, and the best conditions were comprehensively selected by comparing $\mathrm{IC}_{50}, \mathrm{LOD}$, and color development.

\subsection{Selection of Coating Antigen on Test Lines}

Coating antigen was diluted with $\mathrm{PB}(0.02 \mathrm{M}, \mathrm{pH}$ 7.4) and sprayed onto the bottom of nitrocellulose membrane as the test ( $\mathrm{T}$ line) by Dot Dispenser, and then dried in oven at $37^{\circ} \mathrm{C}$ for $6 \mathrm{~h}$. The detection standard curve was established with different coating antigen concentrations, and the best coating antigen condition was optimized combination with low $\mathrm{IC}_{50}$, moderate color, and less amount of coating antigen.

\subsection{Selection of Goat Anti-Mouse IgG on Control Lines}

Under the optimal conditions of coating antigen, goat anti-mouse IgG was diluted with $0.02 \mathrm{M}, \mathrm{pH}$ 7.4 PB and sprayed onto the top of nitrocellulose membrane as the test (C line) by Dot Dispenser, and then dried in oven at $37^{\circ} \mathrm{C}$ for $6 \mathrm{~h}$. The detection standard curve was established with different amounts of goat anti-mouse IgG. The amount of goat anti-mouse IgG was optimized combination with lower $\mathrm{IC}_{50}$ and the release of the labeled antibody on the NC membrane.

\subsection{Principle and Procedure of the TRFICA}

In this case, the TRFICA adopts the micropore method. The detection principle is to mix the antibody-conjugated microspheres and the sample buffer solution for $5 \mathrm{~min}$ at room temperature and then insert the test strip into the micropore. The test strip was put into the cartridge for reading after reaction $8 \mathrm{~min}$. The color intensities on the test lines were tested for using TRFICA reader device. Take $B / B_{0}$ as the $y$-axis $\left(B_{0}\right.$ is the $T / C$ value when no drug is added, and $B$ is the $T / C$ value when the drug concentration is $x$ ), and the concentration of the substance to be tested was the $\mathrm{x}$-axis, then, The detection standard curve of the TRFICA was established though sigmoidal fitting with a four-parameter logictic function. The calculation method as follows: the LOD (the drug concentration when $\mathrm{B} / \mathrm{B} 0=0.1$ ), $\mathrm{IC}_{50}$ (the drug concentration when $\mathrm{B} / \mathrm{B}_{0}=0.5$ ), the range of detection (the drug concentration when $\mathrm{B} / \mathrm{B}_{0}=0.2 \sim 0.8$ ), and the visualization value under UV light (cut-off value).

\subsection{The Specificity of Developed TRFICA}

The specificity of test strips was determined in a cross-reaction study with related compounds. The standard solutions of tylosin, tilmicosin, benfloxacin, enrofloxacin, azithromycin, acetylspiramycin, roxithromycin, clinfloxacin, pefloxacin, furazolidone, spiramycin, furandanone, and furantoin were prepared at different concentrations, respectively, and were tested by the optimal developed TRFICA. The values of cross-reactivity $(\mathrm{CR})$ were determined by $\mathrm{CR}(\%)=\left(\mathrm{IC}_{50}\right.$ of desmycosin $/ \mathrm{IC}_{50}$ of competitor $) \times 100 \%$.

\subsection{The Stability of Developed TRFICA Strip}

Generally, low temperature and dry conditions are conducive to the preservation of immunoassay products; thus, the active coating antigen of TRFICA strip and the monoclonal antibodies of microspheres are both greatly affected by storage conditions. The stability of TRIFCA strips was evaluated by the thermal stability experiments. According to Zhang et al. [35], the storage of immunoassay products at $37^{\circ} \mathrm{C}$ for 7 days is equivalent to that at $4{ }^{\circ} \mathrm{C}$ for 6 months. The prepared TRFICA strips and labeled microspheres were stored in a sealed bag together with the desiccant and then stored in a $37^{\circ} \mathrm{C}$ dry box. The stability of the TRFICA strip could be judged by visual observation and the reading of the reader during the $1,3,5$, and 7 days intervals, respectively. 


\subsection{Sample Pretreatment Method}

The matrix effects of sample were eliminated by optimizing the best dilution, which was confirmed by comparing the standard curves of the diluted sample solution and PB. The milk sample matrix with T\&T as the test object was directly diluted 2 times with $0.02 \mathrm{M}$ PB.

\subsection{Recovery of the Developed TRFICA for Spiked Samples}

The accuracy and precision of developed method were represented by the recovery and the coefficient of variation (CV), respectively. According to the $\mathrm{IC}_{50}, \mathrm{LOD}$, and LOQ of the standard curve of the established method, the recovery and CV were tested by spiking the tylosin or tilmicosin in milk with the high, medium, and low levels, respectively. The $\mathrm{T} / \mathrm{C}$ values of spiked samples were calculated using the established TRFICA, and the following formula to calculate the recoveries: (concentration measured/concentration spiked) $\times 100$. The coefficient of variation $(C V)$ was calculated using the equation: (standard deviation/mean). Three replicates were performed for each concentration $(n=3)$.

\subsection{Comparison of the TRFICA with ELISA and HPLC-MS/MS}

To further confirm the capability and accuracy of the developed TRFICA, a comparison between TRFICA and commercial ELISA kit was conducted by using the spiked milk samples. The milk samples were from Guangdong Wen's Food Group Co., Ltd. The sample preprocessing of ELISA analysis was performed according to the procedure of the ELISA kit instruction manual. Linear regression between the TRFICA and the ELISA was used to evaluate the consistency of these methods. In order to testify the verification of the developed TRFICA, the real samples were randomly selected and analyzed using the TRFICA and the HPLC-MS/MS, respectively.

\section{Results and Discussion}

\subsection{SelectionPreparation of the MAb Labeled Fluorescent Microspheres}

The surface of the fluorescent microspheres is modified with carboxyl groups, which can be coupled with MAb through covalent reactions such as classic active ester reactions. The proper amount of antibodies is important for the detection because a shortfall of antibodies could cause the coagulation of the microspheres, and excess antibodies can increase the cost of the product. Thus, it is necessary to optimize the amount of MAb labeled with fluorescent microspheres. The MAb stock solution $(8.0 \mathrm{mg} / \mathrm{mL})$ was diluted to different amounts of antibodies $(8,16,32,48,96 \mu \mathrm{g})$, then designed to couple with $2 \mu \mathrm{L}$ of the microspheres. The standard curves were established with different amounts of microsphere-labeled antibodies (Figure 2). When the amount of MAb was $32 \mu \mathrm{g}$, the $\mathrm{IC}_{50}$ was the lowest, the sensitivity was higher, and the color of the test strip was appropriate (Figure 3).

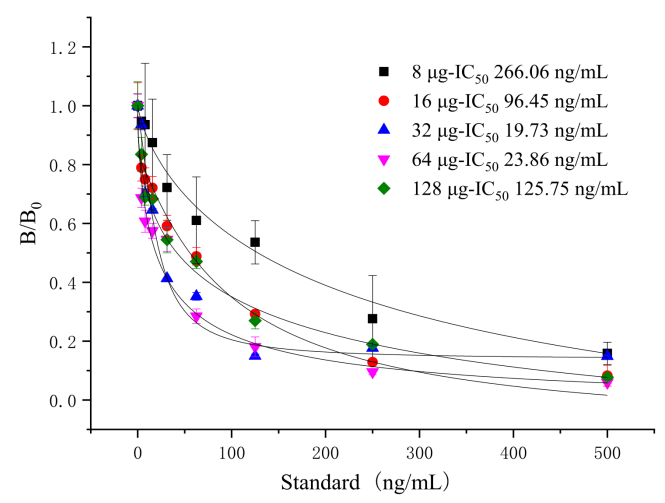

Figure 2. Selecting the amount of MAb for tylosin detection $(n=3)$. 


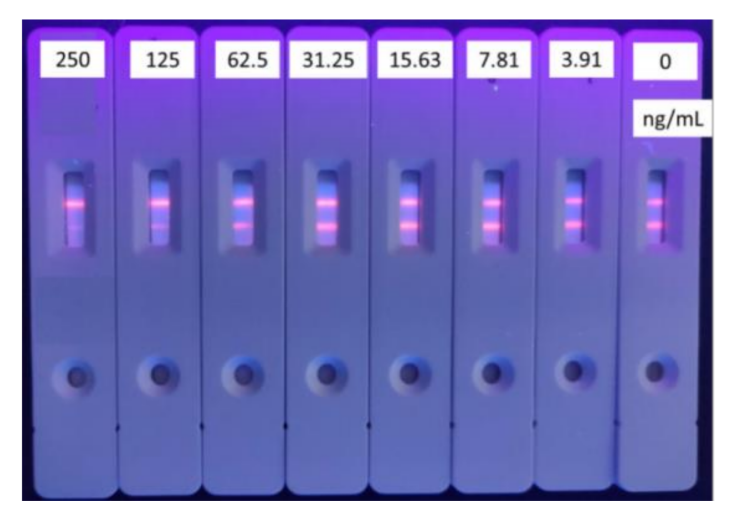

Figure 3. Standard curve for tylosin with the amount of MAb $32 \mu \mathrm{g}(n=3)$. (Dosage of coating antigen and goat anti-mouse $\mathrm{IgG}$ are $1 \mathrm{mg} / \mathrm{mL}$ and $0.093 \mathrm{mg} / \mathrm{mL}$, respectively.)

\subsection{Selection of the Amount of Microsphere-Labeled Antibody}

Excessive microsphere-labeled antibodies will be captured by T-line and C-line, which will cause inaccurate $\mathrm{T} / \mathrm{C}$ readings and poor sensitivity. Conversely, less microspherelabeled antibodies will result in an inaccurate $\mathrm{T} / \mathrm{C}$ value because of the incomplete combination between the substance and the antibody. Here, $100 \mu \mathrm{L}$ tylosin standard solution $(125 \mathrm{mg} / \mathrm{mL})$ was reacted with $1,2,3,4 \mu \mathrm{L}$ of labeled antibody $(32 \mu \mathrm{g} / 6 \mu \mathrm{L})$ in a microwell plate, respectively. Although the cost and the use of antibodies were higher than that of a typical gold-nanoparticle-based strip, the proposed TRFICA strip is still valuable and has potential in practice use since it can be used as a quantitative determination. The optimal amount of microsphere-labeled antibodies were selected by calculating the respective inhibition rates. As shown in Figure 4 and Table 1, there were residual fluorescent microspheres on the NC membrane of the test strip under the amount of $1 \mu \mathrm{L}$ and $2 \mu \mathrm{L}$ microspherelabeled antibody, and the dirty background can easily cause reading interference while the inhibition rate is lower. The results from the time-resolved immunochromatography reader showed that the inhibition rate was the highest when the amount of microsphere-labeled antibody was $3 \mu \mathrm{L}(16 \mu \mathrm{g})$, while the NC membrane of the test strip was released clear.

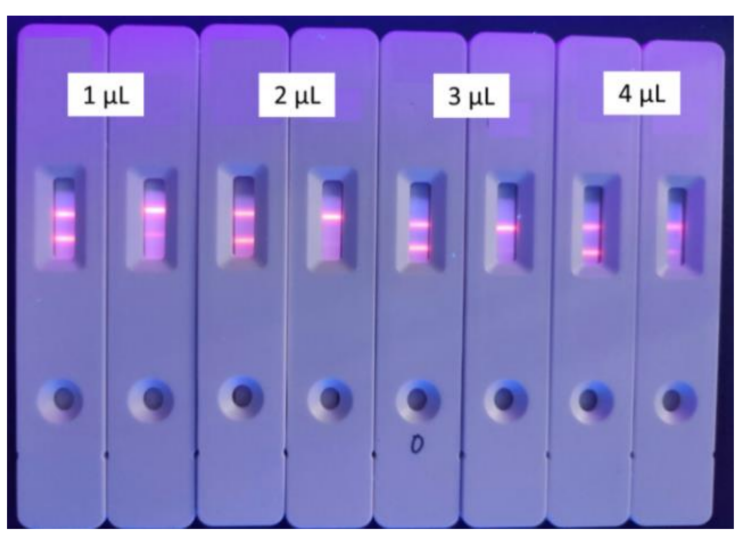

Figure 4. Dosage selection of the labeled antibodies for tylosin $(n=3)$. (Concentration of coating antigen and second antibody are $1 \mathrm{mg} / \mathrm{mL}$ and $0.093 \mathrm{mg} / \mathrm{mL}$.)

Table 1. Dosage selection of the labeled antibodies for tylosin $(n=3)$.

\begin{tabular}{|c|c|c|c|c|c|c|c|c|}
\hline \multirow{2}{*}{$\begin{array}{l}\text { Labeled } \\
\text { Antibodies } \\
\text { Analyst }\end{array}$} & \multicolumn{2}{|c|}{$1 \mu \mathrm{L}$} & \multicolumn{2}{|c|}{$2 \mu \mathrm{L}$} & \multicolumn{2}{|c|}{$3 \mu \mathrm{L}$} & \multicolumn{2}{|c|}{$4 \mu \mathrm{L}$} \\
\hline & Negative & $125 \mathrm{ng} / \mathrm{mL}$ & Negative & $125 \mathrm{ng} / \mathrm{mL}$ & Negative & $125 \mathrm{ng} / \mathrm{mL}$ & Negative & $125 \mathrm{ng} / \mathrm{mL}$ \\
\hline $\begin{array}{l}\mathrm{T} / \mathrm{C}\left(\mathrm{M} \pm \mathrm{SD}^{\mathrm{a}}\right) \\
\text { Inhibition Rate }\end{array}$ & $1.2514 \pm 0.12$ & $\begin{array}{c}0.4188 \pm 0.23 \\
66.5 \%\end{array}$ & $0.8171 \pm 0.14$ & $\begin{array}{c}0.2815 \pm 0.08 \\
65.5 \%\end{array}$ & $1.3649 \pm 0.18$ & $\begin{array}{c}0.2451 \pm 0.07 \\
82.0 \%\end{array}$ & $1.3868 \pm 0.19$ & $\begin{array}{c}0.3470 \pm 0.04 \\
75.0 \%\end{array}$ \\
\hline
\end{tabular}

$\mathrm{SD}^{\text {a }}$ represents the standard deviation of sample. 


\subsection{Selection of the Amount of Coating Antigen on Test Line}

The effective combination between the antigen and antibody was affected by the concentration of coating antigen of T\&T on the test line (T line), which in turn affected the sensitivity. Based on the optimized dosage of antibody and labeled antibody, a standard curve was established with test line by a series concentration of coating antigen $(0.125$, 0.25 , and $0.5 \mathrm{mg} / \mathrm{mL}$ ), respectively. The $\mathrm{IC}_{50}$ value was the lowest when the concentration of coating antigen was $0.25 \mathrm{mg} / \mathrm{mL}$ (shown in Figure 5). Meanwhile, the fluorescent test strip was suitable for color development under ultraviolet light, and the chromatographic background was clean (Figure 6). Finally, the concentration of $0.25 \mathrm{mg} / \mathrm{mL}$ was chosen as the optimal concentration of the coating antigen on the $\mathrm{T}$ line.

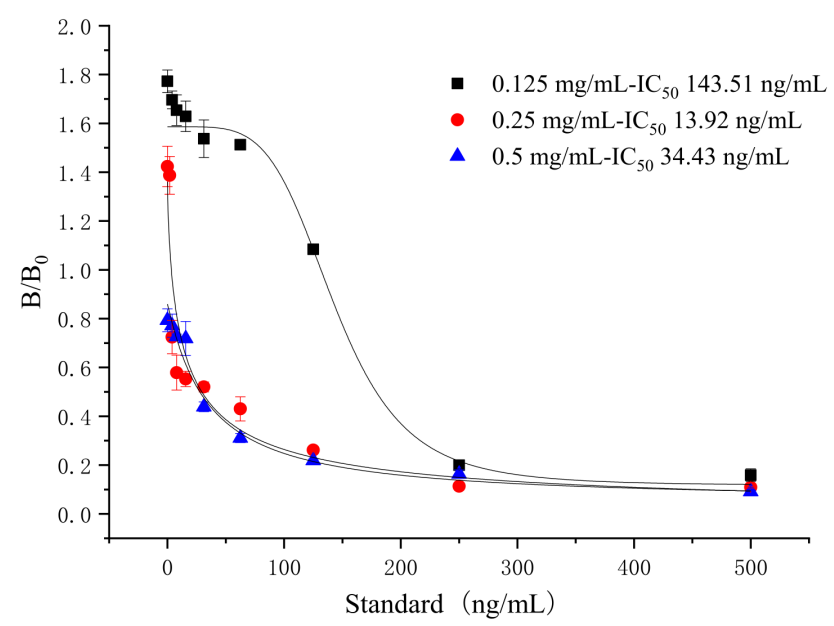

Figure 5. Dosage selection of the coating antigen for tylosin $(n=3)$.

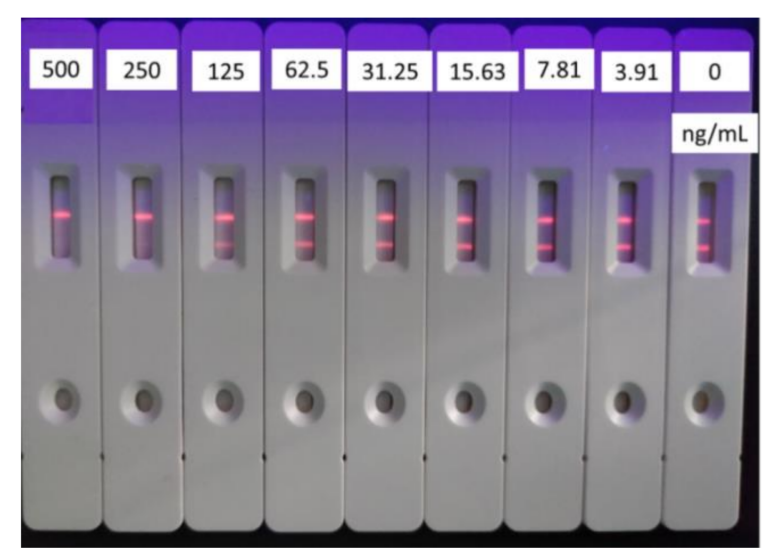

Figure 6. Standard curve for tylosin with coating antigen of $0.25 \mathrm{mg} / \mathrm{mL}(n=3)$. (The concentration of second antibody is $0.093 \mathrm{mg} / \mathrm{mL}$.)

\subsection{Selection of the Amount of Goat Anti-Mouse IgG on Control Line}

A quantitative concentration of goat anti-mouse IgG as coating antigen on the control line (C line) was used to determine the validity of the test strip. The concentration of coated antigen on the control line would cause the color to be too deep or pale, which would lead to an inaccurate $\mathrm{T} / \mathrm{C}$ value or invalid results. As shown in Figures 7 and 8 , the optimized concentration of goat anti-mouse IgG is $0.075 \mathrm{mg} / \mathrm{mL}$, the $\mathrm{IC}_{50}$ was $5.17 \mathrm{ng} / \mathrm{mL}$, and the fluorescent test strip was clear. 


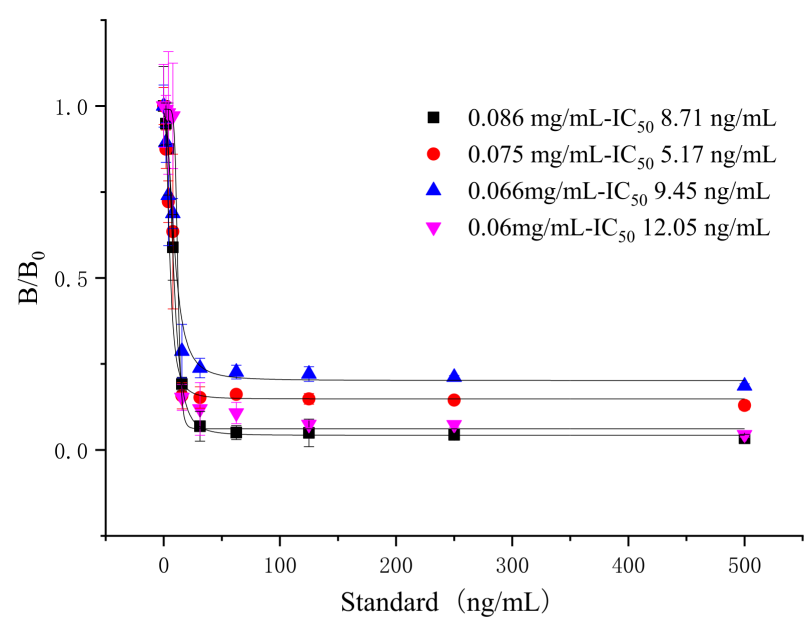

Figure 7. Dosage selection of the goat anti-mouse IgG for tylosin $(n=3)$.

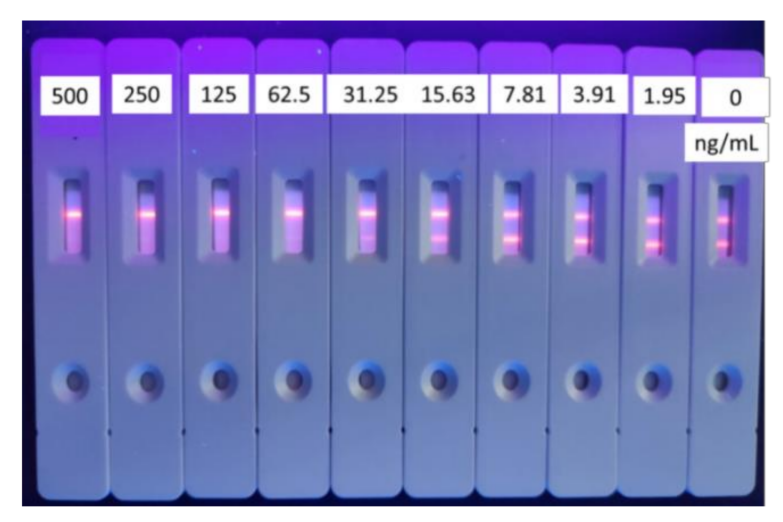

Figure 8. Standard curve for tylosin with goat anti-mouse IgG dosage of $0.075 \mathrm{mg} / \mathrm{mL}(n=3)$.

\subsection{Cross-Reactivities of TRFIA}

Then, the specificity of the TRFIA method for the detection of tylosin was further evaluated. The compounds (as shown in Table 2) with similar chemical structures to T\&T were chosen, and their crossover rates were calculated. As shown in Figure 9 and Table 2, all the selected compounds $(200 \mathrm{ng} / \mathrm{mL})$ were negative, while the T\&T were positive. The TRFIA results indicated their excellent specificity on T\&T $(100 \%)$; they had no crossover rate with other similar compounds, which could meet the demand for the detection of T\&T simultaneously.

Table 2. CRs of related or similar compounds in the TRFICA.

\begin{tabular}{cccc}
\hline Compounds & $\mathrm{IC}_{50}(\mathrm{ng} / \mathrm{mL})$ & Cross-Reactivity (\%) \\
\hline Tylosin & Chemical Structure & & \\
\hline
\end{tabular}


Table 2. Cont.

\begin{tabular}{|c|c|c|c|}
\hline Compounds & Chemical Structure & $\mathrm{IC}_{50}(\mathrm{ng} / \mathrm{mL})$ & Cross-Reactivity (\%) \\
\hline Erythromycin & & $>4000$ & $<0.1$ \\
\hline Norfloxacin & & $>4000$ & $<0.1$ \\
\hline Norfloxacin & & $>4000$ & $<0.1$ \\
\hline Azithromycin & & $>4000$ & $<0.1$ \\
\hline Acetylspramycin & & $>4000$ & $<0.1$ \\
\hline Roxithromycin & & $>4000$ & $<0.1$ \\
\hline Clinafloxacin & & $>4000$ & $<0.1$ \\
\hline Pefloxacin & & $>4000$ & $<0.1$ \\
\hline Furazolidone & & $>4000$ & $<0.1$ \\
\hline Spiramycin & & $>4000$ & $<0.1$ \\
\hline Nitrofural & & $>4000$ & $<0.1$ \\
\hline Furadantin & & $>4000$ & $<0.1$ \\
\hline
\end{tabular}



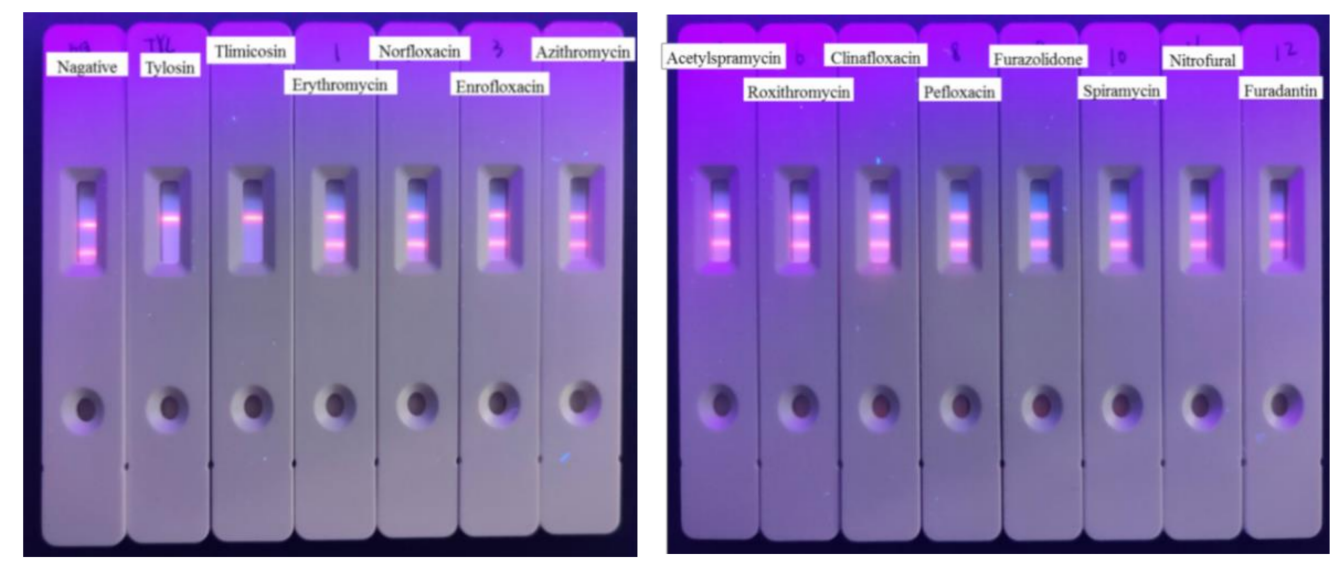

Figure 9. CRs of related or similar compounds in the TRFICA $(n=3)$.

\subsection{Detection of TET in Milk Using the TRFIA Method}

The optimized TRFIA method ( $25 \mu \mathrm{L}$ fluorescent microspheres $(10 \%, 100 \mathrm{~nm})$ labeled Mab, coating antigen $(0.25 \mathrm{mg} / \mathrm{mL})$ on $\mathrm{T}$ line, $\operatorname{IgG}(0.075 \mathrm{mg} / \mathrm{mL})$ on C line) was applied for detecting T\&T in milk. Since milk contains a large amount of protein and fat, the direct application of milk samples will cause greater matrix interference and affect the sensitivity of the method. Hence, the milk was diluted two times by $0.02 \mathrm{M} \mathrm{PB}$ and then loaded with TRFICA. The established standard curve of T\&T is shown in Figure 10. The $\mathrm{IC}_{50}$ of this method to detect tylosin in milk matrix was $4.06 \mathrm{ng} / \mathrm{mL}$, the detection range was $2.35 \sim 7.05 \mathrm{ng} / \mathrm{mL}$, the LOD was $1.72 \mathrm{ng} / \mathrm{mL}$, and the cutoff value was $31.25 \mathrm{ng} / \mathrm{mL}$; the $\mathrm{IC}_{50}$ for tilmicosin was $3.74 \mathrm{ng} / \mathrm{mL}$, the detection range was $1.87 \sim 7.47 \mathrm{ng} / \mathrm{mL}$, the LOD was $1.39 \mathrm{ng} / \mathrm{mL}$, and the cutoff value was $62.5 \mathrm{ng} / \mathrm{mL}$.

In addition, we also evaluated the stability of the TRFICA test strip chromatography. The tylosin (diluted with $0.02 \mathrm{M} \mathrm{PB}, 200 \mathrm{ng} / \mathrm{mL}$ ) was tested using TRFICA test strips stored in a drying cabinet for 1, 3, 5 days, respectively. The results are shown in Table 3. The results of the four measurements were similar and the sensitivity remained unchanged, indicating that the TRFICA test strip had a better stability rate and could be stored for more than 6 months at $4{ }^{\circ} \mathrm{C}$.

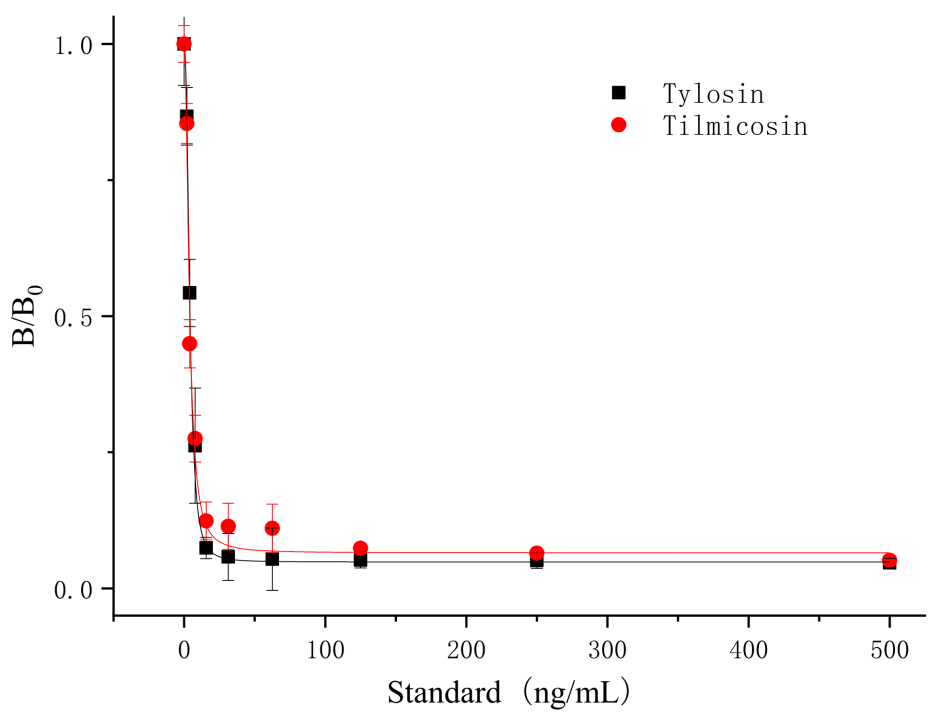

Figure 10. Standard curves for T\&T in milk using TRFICA $(n=3)$. 
Table 3. Stability experiments for TRFICA $(n=3)$ at $37^{\circ} \mathrm{C}$.

\begin{tabular}{cccc}
\hline Days & Negative Samples & Positive Samples & Inhibition Rate (\%) \\
\hline & $\left(\right.$ Mean \pm SD $\left.^{\mathrm{a}}\right)$ & $($ Mean $\pm \mathrm{SD})$ & \\
\hline 1 & $1.2523 \pm 0.19$ & $0.1188 \pm 0.07$ & 90.5 \\
3 & $1.3621 \pm 0.16$ & $0.0872 \pm 0.04$ & 93.6 \\
5 & $1.2398 \pm 0.21$ & $0.1002 \pm 0.09$ & 91.9 \\
7 & $1.2478 \pm 0.15$ & $0.0983 \pm 0.11$ & 92.0 \\
\hline
\end{tabular}

$\mathrm{SD}^{\text {a }}$ represents the standard deviation of the measured values.

The developed standard TRFICA method in this study had high stability, sensitivity, and specificity on the milk matrix. The TRFICA test strip chromatography results showed appropriate color depth, no obvious drag mark, and no matrix interference after diluting milk two times (Figure 11). The TRFICA develops a simple preprocessing milk method, which can meet the national milk limit requirements and is suitable for large-scale screening of T\&T in milk samples.

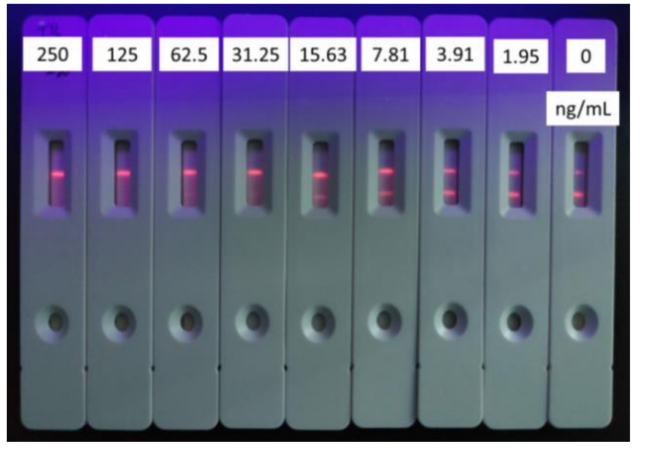

(a)

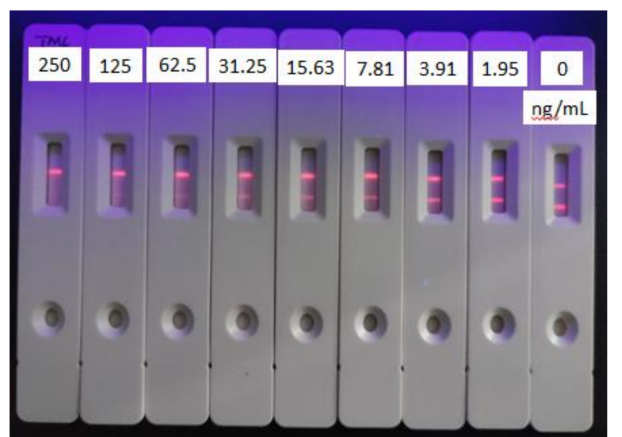

(b)

Figure 11. Standard curves for tylosin (a) and tilmicosin (b) in milk using TRFICA $(n=3)$.

\subsection{Test in Spiked Samples and Real Positive Sample}

To appraise the reliability of these results, all tylosin-and tilmicosin-free samples were used to verify the developed TRFICA and the commercial ELISA kit by calculating recovery rate and CV. Serial concentrations of T\&T standard solutions were spiked in the negative milk samples at $5 \mathrm{ng} / \mathrm{mL}, 10 \mathrm{ng} / \mathrm{mL}$, and $20 \mathrm{ng} / \mathrm{mL}$ (diluted two-fold for direct addition). As shown in Table 4 , the recoveries of T\&T ranged from $80.6 \%$ to $124.5 \%$ for TRFICA with CVs less than $15 \%$. Compared with the results of TRFICA and ELISA, the developed TRFICA had a high recovery rate and good precision, which could meet the detection requirements of actual samples.

Table 4. Recoveries of tylosin-spiked and tilmicosin-spiked samples $(n=3)$.

\begin{tabular}{|c|c|c|c|c|c|c|c|c|}
\hline \multirow[b]{2}{*}{ Samples } & \multirow[b]{2}{*}{ Spiked } & \multirow[b]{2}{*}{$\begin{array}{c}\text { Spiked } \\
\text { Level } \\
(\mathrm{ng} / \mathrm{mL})\end{array}$} & \multicolumn{3}{|c|}{ TRFICA } & \multicolumn{3}{|c|}{ Commercial ELISA Kit } \\
\hline & & & $\begin{array}{c}\text { Measured } \\
(\text { Mean } \pm \text { SD) } \\
(\mathrm{ng} / \mathrm{mL})\end{array}$ & $\begin{array}{c}\text { Recoveries } \\
(\%)\end{array}$ & $\begin{array}{l}\text { CV } \\
(\%)\end{array}$ & $\begin{array}{c}\text { Measured } \\
(\text { Mean } \pm \text { SD) } \\
(\mathrm{ng} / \mathrm{mL})\end{array}$ & $\begin{array}{c}\text { Recoveries } \\
(\%)\end{array}$ & $\begin{array}{l}\text { CV } \\
(\%)\end{array}$ \\
\hline \multirow{6}{*}{ Milk } & \multirow{3}{*}{ Tylosin } & 5 & $5.98 \pm 0.05$ & 119.6 & 12.1 & $6.15 \pm 0.08$ & 122.9 & 1.3 \\
\hline & & 10 & $12.45 \pm 0.04$ & 124.5 & 10.1 & $11.39 \pm 0.03$ & 113.9 & 0.2 \\
\hline & & 20 & $24.08 \pm 0.18$ & 120.4 & 1.9 & $18.41 \pm 0.01$ & 92.1 & 0.1 \\
\hline & \multirow{3}{*}{ Tilmicosin } & 5 & $5.56 \pm 0.03$ & 111.2 & 13.9 & $5.40 \pm 0.08$ & 108.1 & 1.5 \\
\hline & & 10 & $8.05 \pm 0.02$ & 80.6 & 7.2 & $11.21 \pm 0.01$ & 112.1 & 0.1 \\
\hline & & 20 & $17.12 \pm 0.04$ & 85.7 & 4.1 & $19.38 \pm 0.01$ & 96.9 & 0.1 \\
\hline
\end{tabular}


Besides, there were two positive samples with tylosin residues in three real blind samples, and they were confirmed by National Standard HPLC-MS/MS, and the determination results of real positive samples by TRFICA were also consistent with the determination results of HPLC-MS/MS (Table 5). The results indicated that the developed TRFICA could be used for the determination of T\&T simultaneously in real milk samples with high accuracy.

Table 5. The results between TRFICA and HPLC-MS/MS for blind samples.

\begin{tabular}{cccc}
\hline Samples & Analytes & TRFICA (mg/L) & HPLC-MS/MS (mg/L) \\
\hline Milk 1 & Tylosin and Tilmicosin & ND & ND \\
Milk 2 & Tilmicosin & 10.99 & 10.21 \\
Milk 3 & Tilmicosin & 24.08 & 25.93 \\
\hline
\end{tabular}

ND: Not detected.

\section{Conclusions}

TRFICA for detecting T\&T in milk was established in this study. The detection condition was optimized, and the developed standard curves of TRFICA based on the T\&T matrix calibration ranged from 1.87 to $7.47 \mathrm{ng} / \mathrm{mL}$, with $\mathrm{IC}_{50}$ being $4.06 \mathrm{ng} / \mathrm{mL}$ and $3.74 \mathrm{ng} / \mathrm{mL}$, respectively. The constructed TRFICA method has high specificity towards $\mathrm{T} \& \mathrm{~T}$, and there is no cross-reaction rate with other similar compounds. Importantly, in the diluted milk sample, the LOD of the TRFICA ranged from $1.72 \mathrm{ng} / \mathrm{mL}$ to $1.39 \mathrm{ng} / \mathrm{mL}$, with the visual cutoff value being $31.25 \mathrm{ng} / \mathrm{mL}$ and $62.50 \mathrm{ng} / \mathrm{mL}$ for T\&T in milk, respectively. The TRFICA also exhibited high stability at $37^{\circ} \mathrm{C}$. In conclusion, the proposed TRFICA can be regarded as a simple preprocessing method with high specificity, and the detection could be completed in 13 min, which could satisfy the simple, efficient, and specific screening of T\&T residues in milk samples. In the future, how to distinguish between T\&T independently by improving the TRFICA method will be an interesting research direction.

Author Contributions: Conceptualization, Y.W., Y.H. and Y.-D.S.; methodology, Y.W. and Y.-D.S.; software, J.-Y.Y. and L.L.; validation, Y.W., J.-X.H. and Y.-D.S.; formal analysis, J.-Y.Y.; investigation, Y.X.T.; resources, Y.-D.S. and H.W.; data curation, Y.W. and Y.-D.S.; writing-original draft preparation, Y.W. and J.-Y.Y.; writing-review and editing, J.-Y.Y.; visualization, Y.W.; supervision, Y.-D.S. and Z.-L.X.; project administration, Y.-D.S.; funding acquisition, Y.-D.S. and Y.W. All authors have read and agreed to the published version of the manuscript.

Funding: This work was supported by the National Key Research and Development of China (2018YFC1602904), the Guangdong Basic and Applied Basic Research Foundation (2019B1515210025, 2020A1515011238, and 2018B030314005), the Science and Technology Planning Project of the Guangxi (AB18126048), the Science and Technology Planning Project of Guangzhou City (202102080615), and Key-Area Research and Development Program of Guangdong Province (2019B02021101).

Institutional Review Board Statement: Not applicable.

Data Availability Statement: Data is contained within the article.

Conflicts of Interest: The authors declare no conflict of interest.

\section{References}

1. Le, T.; He, H.; Niu, X.; Chen, Y.; Xu, J. Development of an immunochromatographic assay for detection of tylosin and tilmicosin in muscle, liver, fish and eggs. Food Agric. Immunol. 2013, 24, 467-480. [CrossRef]

2. Council Regulation (EC) No 2821/98 of 17 December 1998 amending, as regards withdrawal of the authorisation of certain antibiotics, Directive 70/524/EEC concerning additives in feeding stuffs. Off. J. Eur. Communities 1998, L351, 4-8.

3. Arsic, B.; Barber, J.; Cikos, A.; Mladenovic, M.; Stankovic, N.; Novak, P. 16-membered macrolide antibiotics: A review. Int. J. Antimicrob. Agents 2017, 51, 283-298. [CrossRef] [PubMed]

4. Jones, P.W.; Tarrant, M.E. The effect of various factors on the efficacy of tylosin as a growth promoter in clinically healthy pigs. Anim. Prod. 2010, 34, 115-121. [CrossRef]

5. Cusack, P.M.V. Effect of mass medication with antibiotics at feedlot entry on the health and growth rate of cattle destined for the Australian domestic market. Aust. Vet. J. 2004, 82, 154-156. [CrossRef] 
6. Avci, T.; Elmas, M. Milk and blood pharmacokinetics of tylosin and tilmicosin following parenteral administrations to cows. Sci. World J. 2014, 2014, 869096. [CrossRef]

7. National Standard of China. GB 31650-2019 National Food Safety Standard-Maximum Residue Limits for Veterinary Drugs in Foods; The People's Republic of China: Beijng, China, 2020.

8. Gautier-Bouchardon, A.V.; Reinhardt, A.K.; Kobisch, M.; Kempf, I. In vitro development of resistance to enrofloxacin, erythromycin, tylosin, tiamulin and oxytetracycline in Mycoplasma gallisepticum, Mycoplasma iowae and Mycoplasma synoiae. Vet. Microbiol. 2002, 88, 47-58. [CrossRef]

9. Tong, J.; Rao, Q.; Zhu, K.; Jiang, Z.; Ding, S. Simultaneous determination of five tetracycline and macrolide antibiotics in feeds using HPCE. J. Sep. Sci. 2009, 32, 4254-4260. [CrossRef] [PubMed]

10. Hao, H.; Yao, J.; Wu, Q.; Wei, Y.; Dai, M.; Iqbal, Z.; Wang, X.; Wang, Y.; Huang, L.; Chen, D.; et al. Microbiological toxicity of tilmicosin on human colonic microflora in chemostats. Regul. Toxicol. Pharmacol. 2015, 73, 201-208. [CrossRef]

11. Wang, H.; Ren, L.; Yu, X.; Hu, J.; Chen, Y.; He, G.; Jiang, Q. Antibiotic residues in meat, milk and aquatic products in Shanghai and human exposure assessment. Food Control 2017, 80, 217-225. [CrossRef]

12. Chebira, B.; Boultif, L.; Agabou, A.; Mekroud, A. Validation of a high performance liquid chromatography (HPLC) method to detect and quantify some antibiotics residues in honey. Adv. Anim. Vet. Sci. 2015, 3, 295-301. [CrossRef]

13. Hong, Y.Q.; Guo, X.; Chen, G.H.; Zhou, J.W.; Zou, X.M.; Liao, X.; Hou, T. Determination of five macrolide antibiotic residues in milk by micellar electrokinetic capillary chromatography with field amplified sample stacking. J. Food Saf. 2018, 38 , e12382. [CrossRef]

14. Schwaiger, B.; König, J.; Lesueur, C. Development and validation of a multi-class UHPLC-MS/MS method for determination of antibiotic residues in dairy products. Food Anal. Methods 2018, 11, 1417-1434. [CrossRef]

15. Grutes, J.V.; Ferreira, R.G.; Pereira, M.U.; Candido, F.S.; Spisso, B.F. Development and validation of an LC-MS/MS screening method for macrolide and quinolone residues in baby food. J. Environ. Sci. Health B 2021, 56, 197-211. [CrossRef] [PubMed]

16. Hoff, R.B.; Molognoni, L.; Deolindo, C.T.P.; Vargas, M.O.; Kleemann, C.R.; Daguer, H. Determination of 62 veterinary drugs in feedingstuffs by novel pressurized liquid extraction methods and LC-MS/MS. J. Chromatogr. B. 2020, 1152, 122232. [CrossRef] [PubMed]

17. Chiesa, L.M.; DeCastelli, L.; Nobile, M.; Martucci, F.; Mosconi, G.; Fontana, M.; Castrica, M.; Arioli, F.; Panseri, S. Analysis of antibiotic residues in raw bovine milk and their impact toward food safety and on milk starter cultures in cheese-making process. LWT Food Sci. Technol. 2020, 131, 109783. [CrossRef]

18. Delia, C.F.; David, M.G.; Miriam, B.C.; Antonio, M.D. Critical assessment of two sample treatment methods for multiresidue determination of veterinary drugs in milk by UHPLC-MS/MS. Anal. Bioanal. Chem. 2019, 411, 1433-1442.

19. Zhang, C.; Deng, Y.; Zheng, J.; Zhang, Y.; Yang, L.; Liao, C.; Su, L.; Zhou, Y.Y.; Gong, D.X.; Chen, L.; et al. The application of the QuEChERS methodology in the determination of antibiotics in food: A review. TRAC Trends Anal. Chem. 2019, 118, 517-537. [CrossRef]

20. Mirecki, S.; Nikolić, N. Influence of preservative concentration, pH Value and fat content in raw milk at detection limit of microbial inhibitor tests (Delvotest ${ }^{\circledR}$ Accelerator) for amoxicillin and oxytetracycline. Food Anal. Methods 2016, 9, $2864-2871$. [CrossRef]

21. Litterio, N.J.; Calvinho, L.F.; Floresl, M.M.; Tarabla, H.D.; Boggio, J.C. Microbiological screening test validation for detection of tylosin excretion in milk of cows with low and high somatic cell counts. J. Vet. Med. A 2007, 54, 30-35. [CrossRef]

22. Du, B.; Wen, F.; Guo, X.; Zheng, N.; Zhang, Y.; Li, S.; Zhao, S.; Liu, H.; Meng, L.; Xu, Q.; et al. Evaluation of an ELISA-based visualization microarray chip technique for the detection of veterinary antibiotics in milk. Food Control 2019, 106, 106713. [CrossRef]

23. Huang, J.X.; Yao, C.Y.; Yang, J.Y.; Li, Z.F.; He, F.; Tian, Y.X.; Wang, H.; Xu, Z.L.; Shen, Y.D. Design of novel haptens and development of monoclonal antibody-based immunoassays for the simultaneous detection of tylosin and tilmicosin in milk and water samples. Biomolecules 2019, 9, 770. [CrossRef]

24. Peng, D.P.; Ye, S.Q.; Wang, Y.L.; Chen, D.M.; Tao, Y.F.; Huang, L.L.; Liu, Z.L.; Dai, M.H.; Wang, X.Q.; Yuan, Z.H. Development and validation of an indirect competitive enzyme-linked immunosorbent assay for the screening of tylosin and tilmicosin in muscle, liver, milk, honey and eggs. J. Agric. Food Chem. 2012, 60, 44-51. [CrossRef] [PubMed]

25. Raysyan, A.; Galvidis, I.A.; Schneider, R.J.; Eremin, S.A.; Burkin, M.A. Development of a latex particles-based lateral flow immunoassay for group determination of macrolide antibiotics in breast milk. J. Pharm. Biomed. Anal. 2020, 189, 113450. [CrossRef]

26. Shen, J.Z.; Zhang, Z.; Yao, Y.; Shi, W.M.; Liu, Y.B.; Zhang, S.X. A monoclonal antibody-based time-resolved fluoroimmunoassay for chloramphenicol in shrimp and chicken muscle. Anal. Chim. Acta 2006, 575, 262-266. [CrossRef]

27. Zhang, J.; Gao, L.; Zhou, B.; Zhu, L.; Zhang, Y.; Huang, B. Simultaneous detection of deoxynivalenol and zearalenone by dual-label time-resolved fluorescence immunoassay. J. Sci. Food Agric. 2011, 91, 193-197. [CrossRef]

28. Song, Y.H.; Song, S.S.S.; Liu, L.Q.; Kuang, H.; Guo, L.L.; Xu, C.L. Simultaneous detection of tylosin and tilmicosin in honey using a novel immunoassay and immunochromatographic strip based on an innovative hapten. Food Agric. Immunol. 2016, $27,1-15$. [CrossRef]

29. Lai, X.C.; Lv, X.; Zhang, G.G.; Xiong, Z.J.; Lai, W.H.; Peng, J. Highly specific anti-tylosin monoclonal antibody and its application in the quantum dot bead-based iImmunochromatographic assay. Food Anal. Methods 2020, 13, 2258-2268. [CrossRef] 
30. Zhang, Z.; Liu, J.F.; Yao, Y.; Jiang, G.B. A competitive dual-labelled time-resolved fluoroimmunoassay for simultaneous determination of chloramphenicol and ractopamine in swine tissues. Chin. Sci. Bull 2011, 56, 1543-1547. [CrossRef]

31. Wei, S.; Le, T.; Chen, Y.; Xu, J.; He, H.Q.; Niu, X.D.; Luo, J.H. Time-resolved fluoroimmunoassay for quantitative determination of tylosin and tilmicosin in edible animal tissues. Chin. Sci. Bull 2013, 58, 1838-1842. [CrossRef]

32. Li, X.M.; Wu, X.Z.; Wang, J.; Hua, Q.C.; Wu, J.X.; Shen, X.; Sun, Y.M.; Lei, H.T. Three lateral flow immunochromatographic assays based on different nanoparticle probes for on-site detection of tylosin and tilmicosin in milk and pork. Sens. Actuators B Chemical. 2019, 301, 127059. [CrossRef]

33. Tang, X.; Zhang, Q.; Zhang, Z.; Ding, X.; Jiang, J.; Zhang, W.; Li, P. Rapid, on-site and quantitative paper-based immunoassay platform for concurrent determination of pesticide residues and mycotoxins. Anal. Chim. Acta 2019, 1078, 142-150. [CrossRef] [PubMed]

34. Wang, D.; Zhu, J.G.; Zhang, Z.W.; Zhang, Q.; Zhang, W.; Yu, L.; Jiang, J.; Chen, X.M.; Wang, X.F.; Li, P.W. Simultaneous lateral flow immunoassay for multi-class chemical contaminants in maize and peanut with one-stop sample preparation. Toxins 2019, 11, 56. [CrossRef]

35. Zhang, Y.; Wang, W.; Liu, J.W.; Wang, S. Study on the colloidal gold-based immunoassays for the rapid detection of chloramphenicol residues in animal derived food. J. Chin. Inst. Food Sci. Technol. 2009, 9, 196-200. 